DOI: 10.21608/zvjz.2017.29239.

\title{
Utilization of RT-PCR and Restriction Enzyme Analysis in Detection and Differentiation of Pigeon Paramyxovirus-1 and Newcastle Disease Virus in Pigeons
}

\author{
Esraa E. Hamouda ${ }^{1}$, Nagi A.A. Mohamed ${ }^{2}$, Amal A.M. Eid ${ }^{1 *}$, Abdelshakour N.A.Ismail ${ }^{1}$, \\ Mohamed A. El-Sisi ${ }^{1}$, Ola A.A. Hassanin ${ }^{1}$ and Naser A.Abou-Hashem ${ }^{1}$ \\ ${ }^{1}$ Avian and Rabbit Medicine Department, Faculty of Veterinary Medicine, Zagazig University, \\ 45511, Egypt \\ ${ }^{2}$ Veterinary Hospital, Faculty of Veterinary Medicine, Zagazig University, 45511, Egypt
}

\section{Abstract}

Fifty-one pigeon houses from both commercial lofts and backyard of different ages and breeds were investigated for incrimination of pigeon paramyxovirus-1 (PPMV-1) and/ or Newcastle Disease virus (NDV) during 2013-2015. The results of clinical examination revealed nervous signs (wing paralysis, head tremors, torticollis, opisthotonos and leg paralysis), greenish diarrhea, and respiratory signs, with variable mortalities. The gross lesions included congestion and hemorrhage in brain; nephrosis and/ or nephritis in kidneys, ulcer in intestine and mucoid enteritis. Virus isolation via chicken embryo inoculation revealed embryo congestion and hemagglutination (HA) activity of harvested allantoic fluids were detected 41 samples $(80.39 \%)$ with HA titers ranging from $2^{6}-2^{10}$. The hemagglutination inhibition (HI) results of the same isolates against PPMV-1 and NDV hyper immune sera which prepared in rabbits (1:5dilution) varied from $2^{3}-2^{10}$ in 38 virus isolates. The allantoic fluids of 41 haemaglutinating virus isolates were subjected to Reverse transcriptase polymeraze chain reaction (RT-PCR), Thirtyeight isolates evidenced successful products for partial amplification of fusion protein gene of NDV and PPMV-1 at 356 bp using specific primers. Restriction fragment length polymorphism (RFLP) using a set of three enzymes; HhaI, MspI and MboI. revealed that 9 strains (mesogenic / lentogenic PPMV-1), 27(mesogenic / lentogenic NDV), one velogenic strain for PPMV-1 and the other was NDV. MDT value in ECE revealed $72 \pm 0.0$ and $62.4 \pm 5.89$ indicating that both isolates could be mesogenic. It could be concluded that both NDV and PPMV-1 are cocirculating among pigeons and causing economical losses. Rt-PCR followed by RFLP can be useful rapid tools for detection and identification of both viruses. Beside, in the view of the failure of adopted prophylactic vaccination, both LaSota and Inactivated PPMV-1 vaccines must be included to overcome the impact of aforementioned disease problems in pigeons.

Keywords: PPMV-1, NDV, pigeons, PCR,differentiation,RFLP.

\section{Introduction}

Nervous signs in pigeons represent one of the most important problems in Egypt in last few years and many etololgical agents are involved in such problems as Pigeon paramyxovirus-1, Newcastle disease virus and Paratyphoid [1]

Newcastle Disease (ND) is caused by avian paramyxovirus-1 (APMV-1) which belongs to the genus Avulavirus, sub-family Paramyxovirinae, family Paramyxoviridae, order Mononegavirales [2].

Strains of NDV may differ widely in their virulence for birds and accordingly they can be classified into lentogenic, mesogenic and velogenic. In the succeeding years, several NDVs causing outbreaks in domestic pigeons have been reported in different countries and caused high economic losses [3-6].
Pigeon paramyxovirus-1 (PPMV-1) is a variant form of classical NDV on the basis of characterization by pathogenicity tests and monoclonal antibody binding studies [7, 8, 9].

Both of the above mentioned viruses are characterized by sudden onset and rapid spread with high mortality and morbidity rates 80 and $100 \%$ respectively associated mainly with nervous disorders $[1,10,11]$. The diseases also characterized by gastrointestinal and respiratory signs $[12,13]$ additionally during laying gradually declined and laid eggs were infertile [14].

Pigeon Paramyxovirus-1 and NDV infections threat poultry industry due to continuous out breaks [10, 15-20]. In Egypt, Paramyxovirus-1 was isolated from several disease problems with nervous manifestation 
among pigeons [3, 21-23]. In recent years, reverse transcription-polymerase chain reaction (RT-PCR), restriction enzyme analysis and nucleotide sequencing have been provided for identification and differentiation of individual strains of NDV and PPMV-1 in grouping them into distinct categories on basis of their relatedness or their Occurrence [2426]. The objectives of the present study were detection, isolation, Pathotyping and differentiation of PPMV-1 and NDV from pigeons suffering from nervous signs with greenish diarrhea using traditional laboratory diagnosis as well as RT-PCR and RFLP assays.

\section{Material and Methods}

\section{Clinical and post-mortem examination}

Fifty-one pigeon lofts and backyard houses from different localities with varying ages and breeds within Sharkia Governorate during 2013-2015 were investigated. Clinical and postmortem were recorded.

\section{Virus isolation and Haemaglutination}

Tissue samples including brain, trachea, lungs, liver, spleen, kidneys and pancreas were collected from freshly dead birds for virus isolation. Samples were processed and inoculated in 9-11 day-old Embryonated chicken eggs (ECE) according to the protocol of OIE [13]. The harvested allantoic fluids (AF) were screened by rapid HA test. Quantitative HA was applied [13]. At least three blind passages were applied for each sample to be considered negative. Virus titration was carried out in ECE and dose 50\% (EID ${ }_{50}$ ) was calculated [27].

\section{Preparation of hyper immune serum against NDV and PPMV 1 in rabbits}

Twelve rabbits (Flender and Newzealand), 1.5-2 month old were purchased from private commercial rabbitory at Deyarb-Negm Sharkia Governorate and then divided into 3 equal groups. The first one was kept without any treatment as negative control. Animals of the second group was inoculated intranasally and intraocularlly for $5 /$ successive times $\left(10^{6}\right.$ each dose) weekly by live attenuated LaSota vaccine containing $10^{6} \mathrm{EID}_{50}$, Intervet UK Ltd, Batch no. 14603IJ01 and the animals of third group were inoculated intramuscularly with PPMV-1 (reference PPMV-1) from VET. SER. \& VACC. RES. INST- Cairo-Abbasia, Egypt. Blood samples were collected and the sera were tested by HI after each inoculation with some modification of Abou Hashem procedure [3].

\section{Haemaglutination Inhibition (HI) test}

The HI test was used for titration of hyper immune serum prepared in rabbits by beta method [13] and for identification of naturally isolated viruses using $\alpha$ technique [28].

\section{Molecular identification by RT-PCR and RFLP}

Reverse transcription Polymerase Chain Reaction (two steps RT-PCR) at which the RNA was extracted from HA positive allantoic fluids using Direct-zol RNA MiniPrep Kit, then synthesis of cDNA using SensiFAST cDNA Synthesis kit. The primers used for the identification of PPMV-1 in PCR reaction [29] forward, 5'-GCA GCT GCA CGG ATT GTG GT-3', reverse 5'- TCT TTG AGC AGG AGG ATG TTG -3'

Reverse transcription was carried out at $25^{\circ} \mathrm{C}$ for 10 minutes, then at $42^{\circ} \mathrm{C}$ for 15 minutes. Finally, the reaction was inactivated by heating at $85^{\circ} \mathrm{C}$ for 5 minutes to stop the action of RT enzyme. By the end of this step, pure cDNA was produced and ready for amplification, The PCR was performed in a total volume of $50 \mu \mathrm{l}$ in a sterile $0.2 \mathrm{ml}$ RNase free PCR tube using Dream Taq Green PCR Master Mix (2x) (Thermo scientific) by an initial denaturation at $94^{\circ} \mathrm{C}$ for $2 \mathrm{~min}$, denaturation at $94^{\circ} \mathrm{C}$ for $30 \mathrm{sec}$, followed by annealing $53^{\circ} \mathrm{C}$ for $30 \mathrm{sec}$,extension $72^{\circ} \mathrm{C}$ for $10 \mathrm{~min}$ and final extension step at $72^{\circ} \mathrm{C}$ for 10 min. RTPCR product was visualized by electrophoresis in $1.5 \%$ agarose in $1 \mathrm{X}$ TAE, ethidium bromide was added to a concentration of $0.5 \mu \mathrm{g} / \mathrm{mL}$ for nucleic acid visualization. Then differentiation step between PPMV-1 and NDV was done by restriction fragment length polymorphism (RFLP) using three enzymes; HhaI- MspIMboI from New England Biolabs [29]. The amplified PCR products were digested with restriction enzyme in reaction volume $20 \mu \mathrm{l}$ consisted of $7 \mu \mathrm{L}$ Nuclease free water, $2 \mu 110 \mathrm{x}$ NE Buffer, $1 \mu \mathrm{L}$ Restriction enzyme and $10 \mu$ PCR product. This mixture was incubated at 
$37^{\circ} \mathrm{C}$ for 15 minutes. Digested samples were analyzed on $2 \%$ agarose gel stained with Ethidium bromide $(0.5 \mu \mathrm{g} / \mathrm{mL})$.

\section{Results}

\section{Clinical and PM findings}

The clinical signs of examined pigeons revealed nervous signs (wing paralysis, head tremor, torticollis, opisthotonos and leg paralysis), Greenish diarrhea, respiratory signs, general signs of illness, emaciation, arthritis and sudden death. On necropsy, congestion accompanied by hemorrhages in brain and skull, nephrosis and / or nephritis, ulcer in intestine and mucoid enteritis were seen. Other complications as necrosis in pancreas, fibrinous pericarditis, perihepatities, air Saculitis, necrotic focci with bronzy coloration in liver also observed in examined birds (Figure 1).
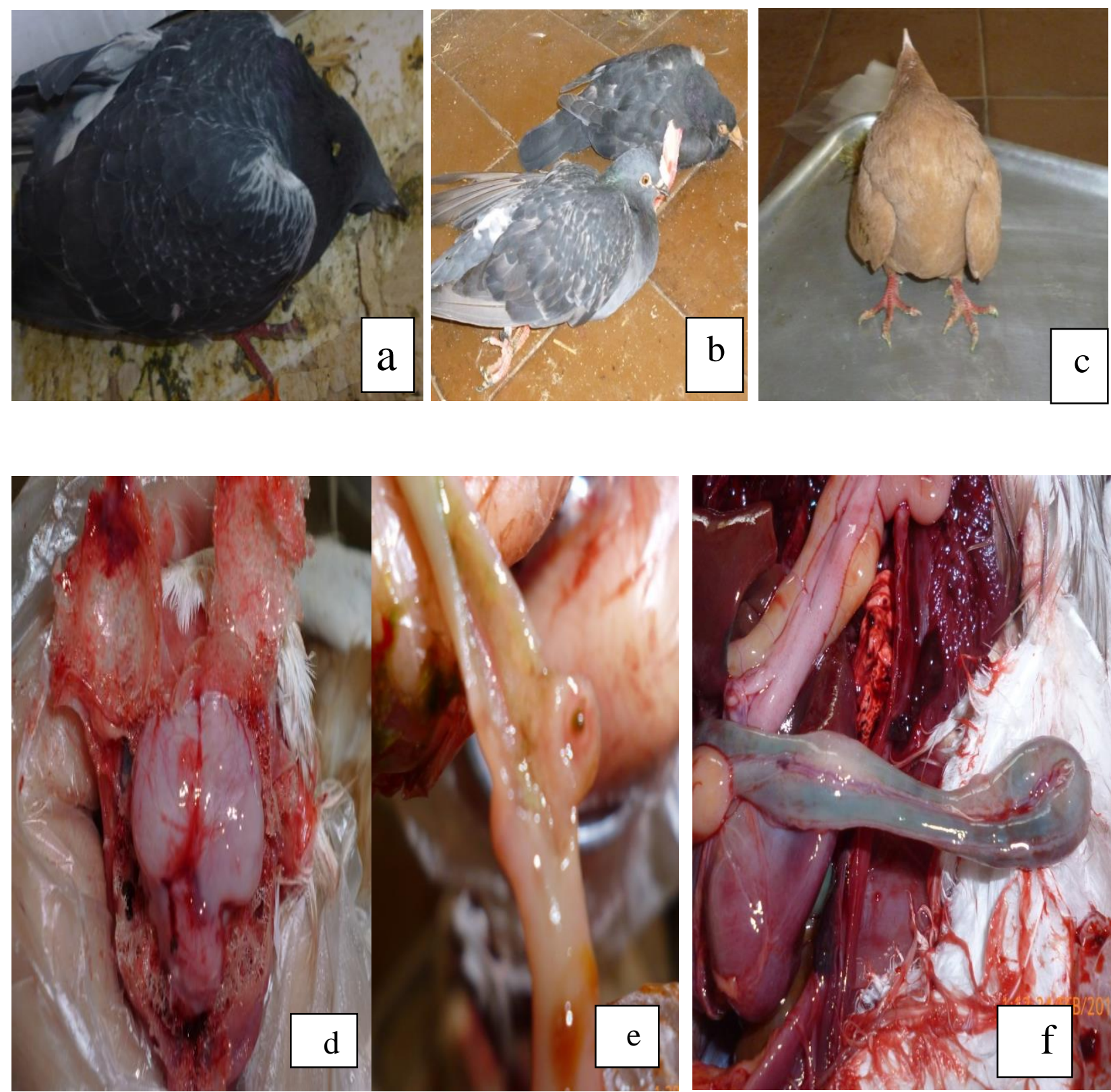

Figure 1: Clinical and PM findings of Naturally infected pigeons with PPMV- 1 and NDV; a- Greenish diarrhea and torticollis in pigeon squab (Flock 19-NDV); b-leg paralysis (Flock 40- PPMV-1); cOpisthotonos in 6 month old pigeons (Flock 48-PPMV-1); d. Congested and hemorrhagic brain in pigeon squab (Flock 17-NDV). e- Ulcer in small intestine in 6 months old pigeons (Flock 47- VPPMV-1); f-Greenish content in intestine (Flock 48-PPMV-1). 


\section{Virus isolation, $\mathrm{HA}$ and $\mathrm{HI}$ results}

Viral isolation revealed embryo deaths with congestion and hemorrhage on embryos within 5 days post infection in 27 samples as early as in the first passage. The HA activity of harvested allantoic fluids were observed in 33 samples from first embryo passages which increased to 41 samples $(80.39 \%)$ in the third passages. The quantitative HA titers of the 41 isolated viruses ranged from $2^{6}-2^{10}$. The quantitative $\mathrm{HI}$ tests of the 41 isolated viruses against PPMV-1 hyper immune serum (1:5 dilution) was ranging from $2^{3}-2^{10}$ and $2^{6}-2^{10}$ for NDV in the same 38 virus samples while the other three failed to be inhibited by hyper immune serum (samples No 10, 38, 44). The results of MDT calculation were $62.4 \pm 5.89$ and $72 \pm 0.0$ for sample 28 and 36 respectively with effective dose $\operatorname{EID}_{50}=10^{8.4} / 0.1 \mathrm{ml}$ and $\mathrm{EID}_{50}=$ $10^{8.5} / 0.1 \mathrm{ml}$.

\section{Molecular identification using RT-PCR}

The allantoic fluids of $41 \mathrm{HA}$ virus isolates which were subjected to RT-PCR revealed successful partial amplification of fusion protein gene of both NDV and PPMV-1 in 38 (92.68\%) virus isolates at 356bp using specific primers (Figure .2).

The three restriction enzymes (HhaI-MspIMboI) were used for digestion of amplified PCR products of $356 \mathrm{bp}$ of $\mathrm{F}$ gene. The results of HhaI enzyme revealed 2 uncleaved and 36 cleaved amplified PCR products (Figure .3). The MspI succeeded to cleave one isolatevelogenic NDV (Isolate No.42) and the other left uncleaved velogenic PPMV-1 (Isolate No. 47). However, MboI succeeded to cleave 27 isolates; mesogenic/lentogenic NDV (Fig. 4) and 9 uncleaved mesogenic/lentogenic PPMV-1(Isolates; 6, 7, 9, 15, 16, 30, 40, 45, 48).

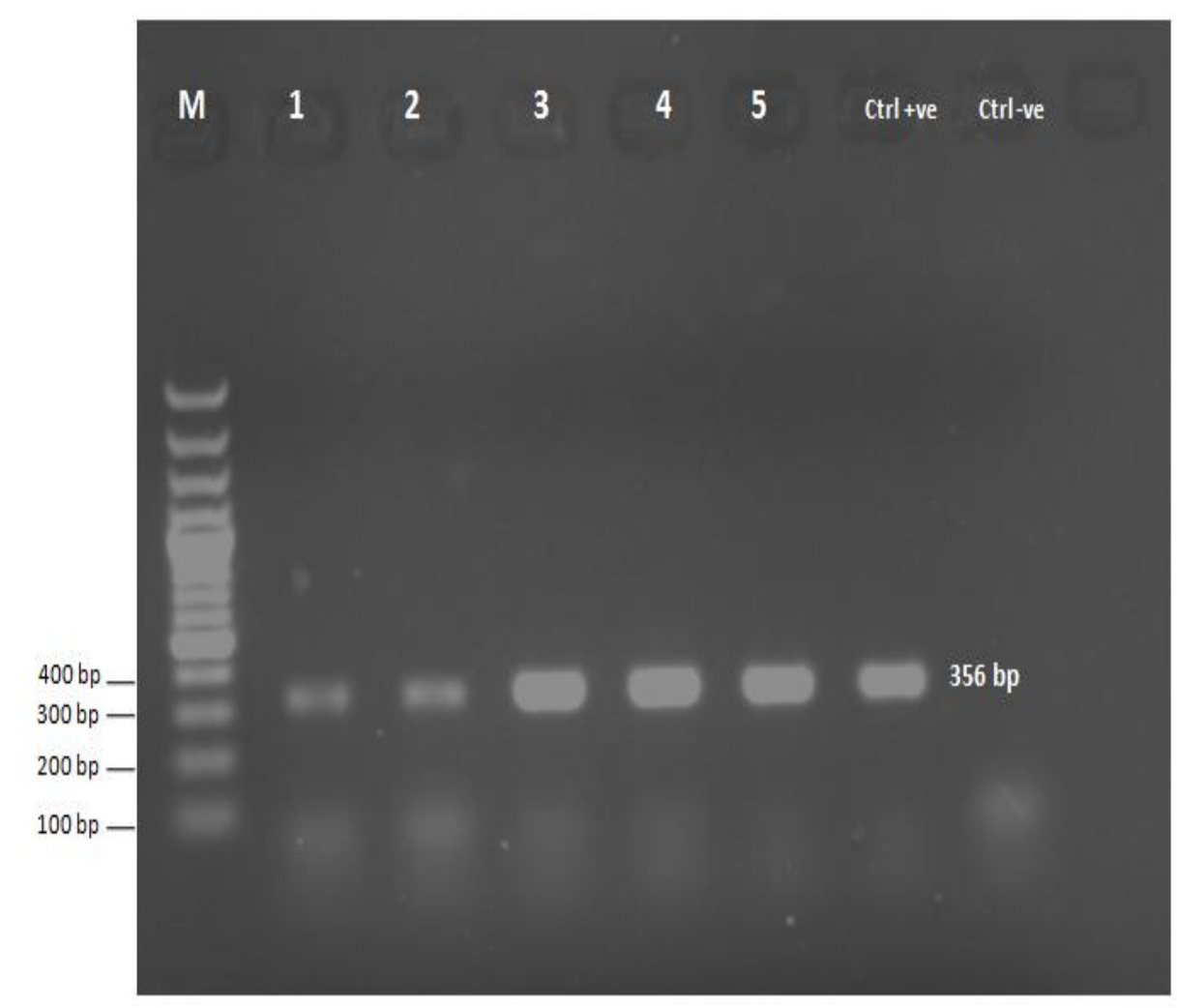

Figure 2: Molecular identification of paramyxovirus using RT-PCR: Lane "M": 100bp DNA ladder (marker), Lanes "1 to 5" positive samples No 6,7,9,15, and 16 and showed bands at $\sim 356$ bp, "Ctrl +ve" control positive La Sota, "Ctrl -ve" Nuclease free-water. 


\section{Discussion}

In recent years a much greater interest was focused to investigate the pathogens in pigeons and viral agents in particular. Pigeons in Egypt are reared for several purposes; meat production, racing, show and hoppy. During the last two decades, there was an increased loss among pigeons associated with nervous disease outbreaks. In order to gain attentiveness into the role of pigeon paramyxovirus -1 a variant of Newcastle disease virus and NDV in current outbreak of neurological disease among pigeons in Sharkia Governorate, 51 pigeon houses of both commercial and backyard rearing were investigated for incrimination of either PPMV1 or NDV.

The current results revealed that examined pigeons suffered from nervous signs, head tremors were the most common followed by torticollis, leg paralysis, wing paralysis then opisthotonos. Greenish diarrhea, respiratory and general signs of illness. Similar clinical findings were recorded associated with pigeon paramyxovirus-1 infections worldwide $[10,30$, $31,32]$ and in Egypt [3,11, 33 ,34]. Undistinguishable clinical signs were recorded in NDV in pigeons [7].

On necropsy, congestion in brain was observed, with hemorrhages on outer and inner aspects of skul1. Enteritis came after brain lesions in the examined birds that recorded in PPMV-1 [3,14,33-40] and also recorded in NDV [41,42], beside ulcer in intestine.

The ECE inoculation for isolation of some viruses especially HA viruses as PPMV-1 is recommended as a preliminary method for virus isolation and propagation [13]. In this study, suspensions free from bacterial and contamination in ECE revealed embryo congestion. The HA activity was observed in 41 samples $(80.39 \%)$. The obtained outcomes are in agreement with the earlier studies related to ECE inoculation and HA activity of paramyxovirus $-1[3,13,33,34,41,43]$.

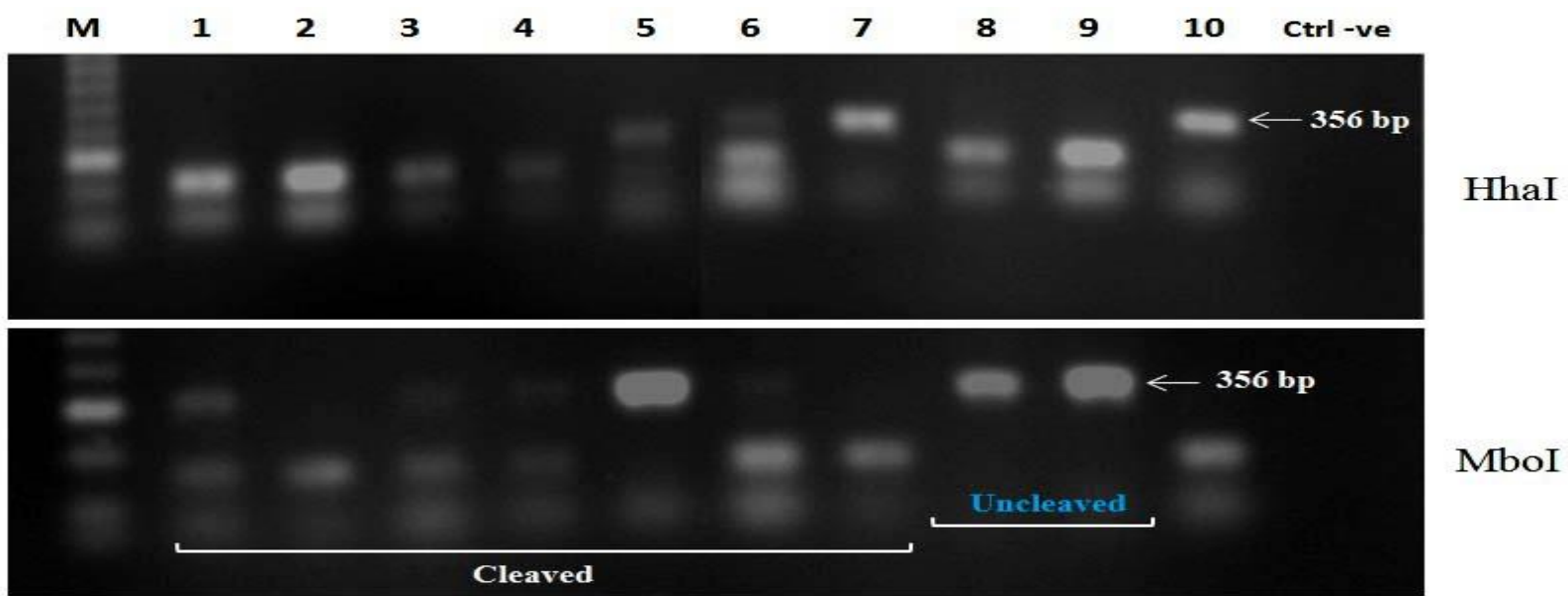

Figure 3: Restriction enzymes cleavage pattern of 356 bp F gene PCR product of NDV isolates in $2 \%$ agarose gel. Lane M 100bp DNA ladder; Upper: Cleavage pattern of HhaI indicates the mesogenic/lentogenic NDV/PPMV-1 samples in lanes (1 to 10). Lower: Cleavage pattern of MboI: cleavage in samples; 1 to 7 and 10 lanes indicate mesogenic/lentogenic NDV; uncleaved in lanes 8 and 9 indicates mesogenic/lentogenic PPMV-1. 
Neither clinical signs nor PM lesions may be pathogenomic for NDV or PPMV-1 infection but only a suggestion for the NDV or PPMV-1 incrimination. Complicated findings like nematodes, cestodes, sarcocysts as well as secondary bacterial infection signs were observed among our examined pigeons [44, 45]. Analogous clinical disease profile was recorded in pigeons by Abouhashem [3] and El-Sisi et al. [46] who reported that mixed viral, bacterial and parasitic infections can increase the severity of the disease among affected pigeons.

The quantitative HA and HI tests revealed HA titers of the 41 isolated viruses ranging from $2^{6}-2^{10}$. The HI results of the same viruses against PPMV-1 and NDV hyper immune serum (1:5dilution) ranging from $2^{3}$ $2^{10}$ and $2^{6}-2^{10}$ respectively in 38 virus samples. Similarly, the aforementioned viruses were identified by Abouhashem [3] Alexander et al. [10] Ibrahim et al. [34] and Guo et al. [43]. While the other three failed to be inhibited by hyper immune serum. This result could be attributed to other HA viral agents such as Avian Influenza Viruses [47]

The mean death time of two selected NDV isolates (28 and 36) were 62.4 \pm 5.89 and $72 \pm 0.0$ while $\mathrm{EID}_{50}$ for the same isolates were $10^{8.5} / 0.1 \mathrm{~mL}$ and $10^{8.4} / 0.1 \mathrm{~mL}$ respectively, that suggesting being mesogenic pathotype [48].

Currently RT-PCR has been employed for definite identification paramyxovirus-1 \& NDV as well as differentiation of paramyxoviures-1 from other HA viruses as AIV [13, 24]. Our allantoic fluids of $41 \mathrm{HA}$ positive virus isolates were subjected to RTPCR. Thirty-eight isolates evidenced successful products for partial amplification of fusion protein gene of NDV and PPMV-1 at $356 \mathrm{bp}$ using specific primers. These results are supported by Naveen et al. [29] findings that used the same protocol for molecular identification of paramyxoviruses.

Molecular characterization of PPMV-1 and NDV using RFLP is advised recently by many authors $[24,49,50]$. The technique of RT-PCR followed by restriction enzymes to differentiate between NDV and PPMV-1 and their pathotypes is a valuable practice for molecular epidemiology of avian and pigeon paramyxovirus discrimination $[29,51]$ In a trial to differentiate the molecularly identified viruses as paramyxovirus -1, a set of three enzymes HhaI, MspI and MboI were sufficient to differentially detect APMV-1 and PPMV1 viruses and their pathotypes.

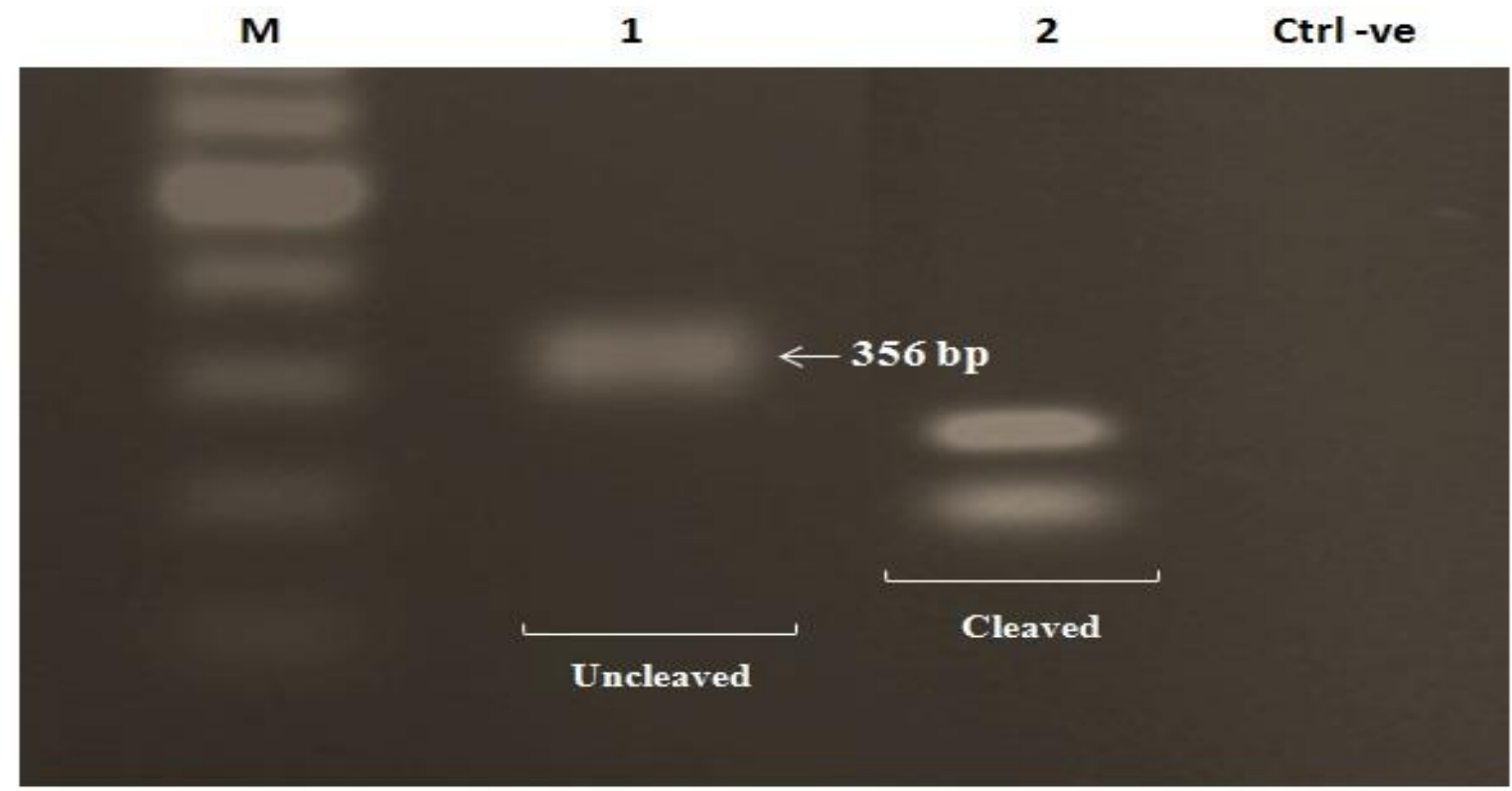

Figure 4: Restriction enzymes cleavage pattern of 356 bp F gene PCR product of pigeon paramyxovirus isolates in $2 \%$ agarose gel by using Msp1 enzyme Lane 1 cleavage pattern of Msp1 for velogenic PPMV-1 (47) but Lane 2 cleavage pattern of Msp1 for velogenic ND (42). 
The RE digestion of 356 bp PCR amplicon of $\mathrm{F}$ gene with HhaI resulted in cleavage of mesogenic and lentogenic NDV and PPMV-1. Two distinct bands of approximately 250 and 100 bp size, whereas, vvNDV and velogenic PPMV-1 isolates remained uncleaved. The first step of separation revealed 2 uncleaved and 36 cleaved agents. These sequlae are in harmony with those reported by Naveen et al. [29] who stated that the aforementioned enzyme is helpful in parting PPMV-1 and NDV pathotypes.

Secondly, since MspI enzyme cleaves only the velogenic NDV [29], in our study this enzyme succeeded to cleave one isolate as a velogenic NDV (42) and failed to cleave velogenic PPMV-1(47). MboI digestion of the $F$ gene amplicon of the lentogenic and mesogenic NDV and PPMV-1 strains resulted in two distinct bands, whereas reference vvNDV and all the PPMV-1 isolates lacked restriction site. So Mob1 failed to cleave 9 virus samples (mesogenic / lentogenic PPMV1) (6-7-9-15-16-30-40-45-48) but cleaved mesogenic / lentogenic APMV-1(27 isolate) . Our current consequences for the three enzymes refer to ten PPMV-1 including one velogenic, while the other nine lies in mesogenic/ lentogenic pathotype group and 28 NDV including one velogenic and 27 mesogenic/ lentogenic pathotype group Similarly, Naveen et al. [29] concluded the previously discussed RT-PCR followed by RE are successful in differentiation of NDV and PPMV-1 isolates.

\section{Conclusion}

In conclusion, both classic NDV and its variants PPMV-1 are incriminated in nervous disease problems that hitting pigeons in Sharkia Governorate. The use of RT-PCR followed by RFLP could be valuable method for differential diagnosis of ND and PPMV-1. Evaluation of presently applied prophylactic regimens including vaccines in relation to different paramyxoviruses of pigeons. Also, the inclusion of LaSota live attenuated beside inactivated PPMV-1 in the same prophylactic regimen in pigeons.

\section{Acknowledgements}

The authors are grateful for Dr. Shimaa Mohammed Galal Mansour, Assistant Prof. of
Virology, Dr. Eman ElAraby, Professor of Genetics and Genetic Engineering, and Dr. Reham Mohammed Mohammed El Bakery, Lecturer of Avian and Rabbit Diseases, Faculty of Veterinary Medicine, Zagazig University for collaboration in this work.

\section{Conflict of interest}

The authors declare no conflict of interest.

\section{References}

[1] Weber, A.; Potel, J and Schafer-Schmidt.; (1995): Occurance of listeria monocytogenes in feral samples of pigeons. Berliner and Munchener Tierarztliche Wochenschrift, 108(1):2627.

[2] Lamb R.A.; Collins P.L.; Kolakofsky D.; Melero J.A.; Nagai Y.; Oldstone M.B.A.; Pringle C.R. and Rima B.K. (2005): Family paramyxoviridae. In: Fauquet C.M.; Mayo M.A.; Maniloff J.; Desselbreger U. and Ball L.A. Virus Taxonomy. The eighth report of the International Committee on Taxonomy of Viruses. Elsevier Academic Press, San Diego, pp. 655-668.

[3] Abouhashem, N.A.; (1993): Studies on some paramyxovirus infection in pigeons M.V.SC. Thesis, Zagazig University.

[4] Kataria J.M.; Dhama K.; Rahul S.; Singh S.D. and Sah R.L. (2004): Occurrence of Newcastle disease in pigeons in India and immune response following immunization with inactivated homologous and heterologous paramyxovirus. Indian Journal of Comparative Microbiology Immunology and Infectious Diseases, 25: 53-56.

[5] Naveen K.A.; Singh S.D. and Mohanty T.R. (2009): Pathobiological and molecular characterization of an Indian isolate of Pigeon paramyxovirus type-I. Indian Journal of Veterinary Pathology, 33: 58-61.

[6] Dortmans J.C.; Koch G.; Rottier P.J. and Peeters B.P. (2011A): A comparative infection study of pigeon and avian paramyxovirus type 1 viruses in pigeons: evaluation of clinical signs, virus 
shedding and seroconversion. Avian Pathology, 40: 125-13.

[7] Alexander, D.J and Parsons, G.; (1984): Avian paramyxovirus type 1 infections of racing pigeons: 2 pathogenicity experiments in pigeons and chickens. Veterinary Record, 114, 466-469.

[8] Alexander, D.J and Senne, D.A.; (2008): Newcastle disease, other avian paramyxoviruses, and pneumoviruses infections. In: Saif YM (ed) Diseases of Poultry, 12th ed, Blackwell Publishing, Ames, pp. 75-116.

[9] Dortmans, J.C.; Rottier, P.J.; Koch, G and Peeters, B.P.; (2011B): Passaging of a Newcastle disease virus pigeon variant in chickens results in selection of viruses mutations in the polymerase complex enhancing virus replication and virulence. Journal of General Virology, 92: 336-345.

[10] Alexander,D.J.; Russel,P.H.; Parsons .G.; Abu -Elzein,E.M.M.; Fleury,H.J.A.; Guittet,M.; Kaleta,E.F.; Kihm,U.; Kosters,J.; Lomniczi,B.; Meister,J.; Meullemans,G.; Nerome,K.; Petek,M.; Pokomunski,S.; Polten,B.; Prip,M.; Richeter,R.; $\quad$ Saghy,E.; Samberg,Y.;Samberg,Y.; Spanoghe,L and Tumova,B.;(1985): Antigenic and Biological characterization of avian paramyxovirus type -1 isolates from Pigeons (An international collaborative study). Avian Pathology, 14: 365-373.

[11] Eisa, M.; and Omer, E. A.; (1984): A natural outbreak of Newcastle disease in pigeons in Sudan. Veterinary Record., 114: 297.

[12] Alexander, D.J.; Aldous, E.W. and Fuller, M.C.M. (2012): The long view: a selective review of 40 years of Newcastle disease research. Avian Pathology, 41: 329-335.

[13] OIE Terrestrial Manual., (2012): Newcastle disease, chapter 2.3.14. Version adopted by the world Assembly of Delegates of the OIE in May 2012. PN. 3,7,8 http: //www.oie.int/en/ourscientific-expertise/referencelaborties/list-of-laborties/).
[14] Povazsan, J.; Bitay, Z.; Saghy, E and Meder, M.; (1984): Occurrence of an epidemic disease caused by paramyxovirus in Hungary in racing pigeons Flocks. I. Clinical, pathology and epidemiological observation. $\mathbf{J}$ Magyar Allatorovosok lap ja.39 (7) 105208.

[15] Anonymous.; (1984): Newcastle disease: outbreaks linked to pigeons. Veterinary Record, 114:305-306.

[16] Alexander, D.J.; Manvell, R.J.; Frost, K.M.; Pollitt, W.J.; Welshman, D and Perry, K.; (1997): Newcastle disease outbreak in pheasants in Great Britain in May 1996. Veterinary Record, 140: 2022.

[17] Alexander, D.J.; Morris, H.T.; Pollitt, W.J.; Sharpe, C. E.; Beckford,R. L and Beckford,R. L and Sainsbury, R.M. (1998): Newcastle disease outbreaks in domestic fowl and turkeys in Great Britain during 1997. Veterinary Record, 143:209-212.

[18] Werner, O.; Romer - Oberdorfer, A.; Kollner, B.; Manvell, R.J and Alexander, D.J.; (1999): Characterization of avian paramyxovirus type 1 strains isolated in Germany during 1992 to 1996. Avian Pathology, 28:79-88.

[19] Liu, H.; Wang, Z.,; Son, C.; Wang, Y.; Yu, B and Zheng, D.; (2006): Characterization of pigeon-origin Newcastle disease isolated in China. Avian Diseases, 50, 636-640.

[20] Irvine, R.M.; Aldous, E.W.; Manvell, R.J.; Cox, W.J.; Ceeraz, V and Fuller, C.M. (2009): Outbreak of Newcastle disease due to Pigeon paramyxovirus type 1 in grey partridges (Perdix Perdix) in Scotland in October 2006.Veterinary Record, 165: 531-535.

[21] Mahmoud A.A. (1983): The role of pigeon in transmitting some poultry pathogenic viruses. Ph.D. Thesis (Poultry Diseases), Faculty of Veterinary Medicine, Zagazig University.

[22] Mohamed A.E. (1986): Viral infections associated with nervous manifestations in pigeons. M.V.Sc., Thesis (Poultry 
Diseases), Faculty of Veterinary Medicine, Zagazig University.

[23] Shakal M.A. (1990): Studies on paramyxovirus infection in pigeons in Egypt .Ph.D., Thesis (Poultry Diseases), Faculty of Veterinary Medicine, Cairo University.

[24] Ujvari, D.; Wehmann, E.; Herczeg, J and Lomniczi, B.; (2006): Identification and subgrouping of pigeon type Newcastle disease virus strains by restriction enzyme cleavage site analysis. Journal of Virological Methods, 131, 115-121.

[25] Cattoli G.; Susta L.; Terregino C. and Brown C. (2011): Newcastle disease: a review of field recognition and current methods of laboratory detection. Journal of Veterinary Diagnostic Investigation, 23: 637-656.

[26] Tirumurugaan K.G.; Kapgate S.; Vinupriya M.K.; Vijayarani K.; Kumanan K.; Elankumaran S. (2011): Genotypic and pathotypic characterization of Newcastle disease viruses from India. PLoS One, 6: e28414.

[27] Villegas P. (2006): Titration of Biological Suspension. A laboratory Manual for Isolation and Identification of Avian pathogens. 4th Ed., pp. 249.

[28] Thayer, S.G. and Beard, C.W. (2008): Serologic procedures. In: A Laboratory Manual for the identification and characterization of avian pathogens. Dufour-Zavala, L. (Ed.), Aaap, Jacksonville, Florida. pp: 222-229. 18.

[29] Naveen,K.A .; Shambhu, S. D.; Kataria,J. S.; Barathidasan, R ;and Dhama, K.; (2013): Detection and differentiation of pigeon paramyxovirus serotype-1 (PPMV-1) isolates by RT-PCR and restriction enzyme analysis .Trop Anim Health Prod 45:1231-1236.

[30] Alexander, D.J.; Lister, S. A and Wilson, G.W.C.; (1984): Avian paramyxovirus type -1 infection of racing pigeon: 5 continued spread in 1984. Veterinary Record 118 (15) 424- 427.
[31] Kathleen, M. J and Douglas, W. K.; (1992): Paramyxovirus-1 in feral pigeons (Columba livia) in Ontario Can Veterinary Journal 1992; 33: 796- 800.

[32] Meulemans, G.; van den Berg, T.P.; Decaesstecker, $\mathrm{M}$ and Boschmans, M.; (2002): Evolution of pigeon Newcastle disease virus strains Avian Pathology 31:515-519.

[33] Ibrahim, R.S.; Abdel-Motelib, T.Y.; and Abdel-Hafez, M.S.; (2005): Paramyxovirus infection in pigeons. Assiut Veterinary Medical Journal Vol.51 No.104.

[34] Ibrahim, R.S.; Moustafa, F.A and Mubarak, M. (2000): Paramyxo virus infection in pigeons. Assiut Veterinary Medical Journal. Vol 44, No. 87.

[35]Richter,R.;(1983):paramyxovirus infektion bei tauben. III. Tagung uber vogelkrankheiten,Schwerpunkt taube Fachgruppe-Geflugel der DVG,Munchen, Tagungsber. p. 85-95. Cited by Shakal (1990).

[36] Schusser, G.; Lechner, C.; Loupal, G.; Worgotter, J and Vasicek.; (1984): Paramyxovirus-1 infection in pigeons in Austria. Wien. Tierarzti. Mschr. 71: 353365.

[37] Fischer, E.; Frese, k.; Meister.J. and Kaleta, E.F.; (1986): HistoPathology of spontaneous PMV-1 infection of pigeons.Dt.Vet.Med.Gesellschaft.141149.

[38] Mangat, A.P.S.; Singh,G. and Gill,B.S (1988):An outbreak of paramyxovirus encephalomyelitis in racing pigeons in India. Veterinary Record.123 (19) 496.

[39] El-Mubarak, A. K.; Elzein, A. E. E. E.; Elgasim, A. I. A and Abu Elzein, E. M. E.;(1990): Note on the pathology of experimental infection of pigeons by the pigeon paramyxovirus type-1 (PPMV-1). Revue-d'Elevage-et-de-Med.Vet.DesPays-Tropica, 43: 441-444 (Veterinary Bulletin , 62:1870, 1992).

[40] Zanetti,F.; Mattiello,R.; Garbino,C.; Kaloghlian,A.; Terrera, M,V.; Bovis,J.; Palma,E.; Carrillo,E and Berinston, A.; 
(2001) : Biological and molecular characterization of a pigeon Paramyxovirus type-1 isolate found in Argentina. Avian Diseases 45:567-571.

[41] McFerran J.B. and McCracken R.M. (1988): Newcastle Disease. In: Newcastle disease (Alexander D.J., Ed.). Kluwer Academic Publishers, Boston, 161-183.

[42] Shaheen S.; Anjum A.D. and Rizvi F. (2005):Clinico-pathological observations of pigeons (Columba livia) suffering from Newcastle disease. Pakistan Veterinary J., 25(1): 5-8.

[43] Guo, H.; Liu,X.; Han, Z.; Shao, Y.; Chen,J.; Zhao, S .; Kong, X and Liu, S.; (2013):Phylogenetic analysis and comparison of eight strains of pigeon paramyxovirus type 1 (PPMV-1) isolated in China between 2010 and 2012. Arch Virol 158:1121-1131.

[44] Saif Y.M.; Fadly A.M.; Glisson J.R.; McDougald L.R.; Nolan L.K. and Swayne D.E. (2008): Diseases of Poultry. $12^{\text {th }}$ ed, Blackwell Publishing Professional.

[45]Mazumder A.C.; Khatun S.; Nooruzzaman M.; Chowdhury E.H.; Das P.M. and Islam M.R. (2012): Isolation and identification of Newcastle disease viruses from field outbreaks in chickens and pigeons. Bangl. Vet., 29 (2): 41-48.

[46] El-Sisi, M.A.; Shakal, M.A.; Chanem, I.A.; and Abouhashem, N.A.; (1995): Recent situation of pigeon paramyxovirus infection in pigeon in
Egypt. Veterinary., Giza.vol.43, No. 1.109-113.

[47] Shimaa M. G. Mansour, Reham M. ElBakrey, Haytham Ali, David E. B. Knudsen \& Amal A. M. Eid (2014): Natural infection with highly pathogenic avian influenza virus $\mathrm{H} 5 \mathrm{~N} 1$ in domestic pigeons (Columba livia) in Egypt, Avian Pathology, 43:4, 319-324,

[48] Kim L.M.; King D.J.; Suarez D.L.; Wong C.W. and Afonso C.L. (2007): Characterization of class I Newcastle disease virus isolates from Hong Kong live bird markets and detection using realtime reverse transcription-PCR. J. Clin. Microbiol. 45: 1310-1314.

[49] Kant, A.; Koch, G.; Van Roozelaar, D.; Balk, F.; and Ter Huurne, A.; (1997): Differentiation of virulent and nonvirulent strains of Newcastle disease virus within 24 hours by polymerase chain reaction. Avian Pathology, 26, 837-849.

[50] Nanthakumer, T.; Kataria, R.S.; Tiwari, A.K.; Butchaiah, G. and Kataria, J.M.; (2000): Pathotyping of Newcastle disease viruses by RT-PCR and restriction enzyme analysis. Veterinary Research Communication, 24, 275-286.

[51] Naveen, K.A .; Singh, S. D.; Kataria,J. S.; Barathidasan, R .; and Dhama, K.; (2014) :Molecular characterization and phylogenetic analysis of PPMV-1 Indian isolates .Journal of biological sciences (14):134-141. 


\section{الملخص العربي}

استخدام اختبار البلمرة المتسلسل وانزيمات القطع في تحديد وتمييز فيروس الباراميكسوـا وفيروس مرض

النيو كاسل في الحمام

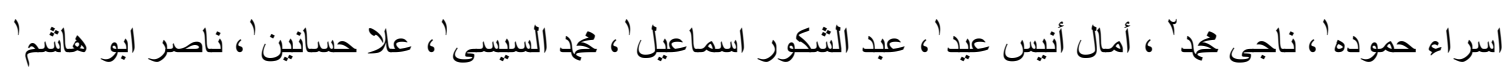

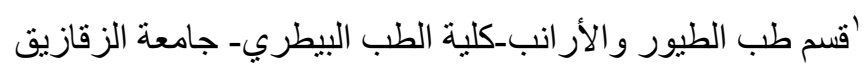

'المستشفي البيطري- كلية الطب البيطري- جامعة الزقازيق

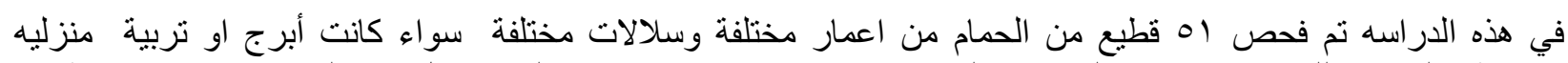

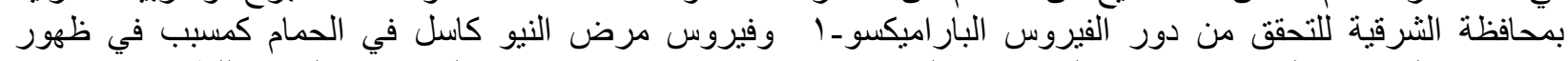

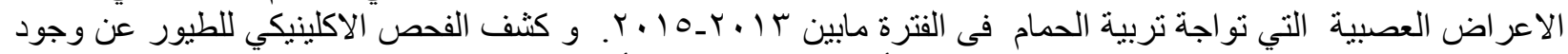

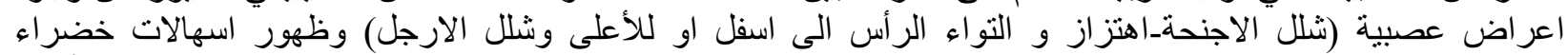

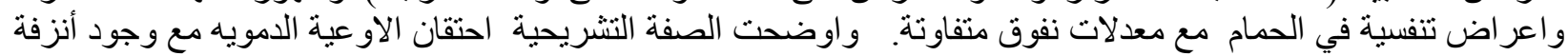

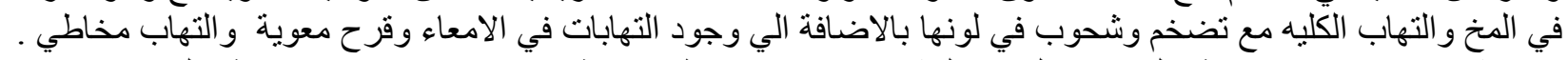

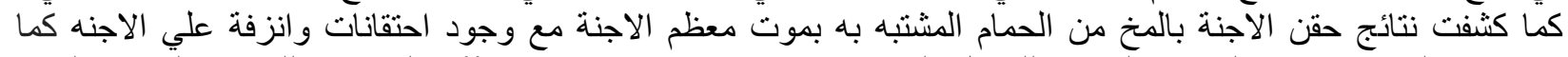

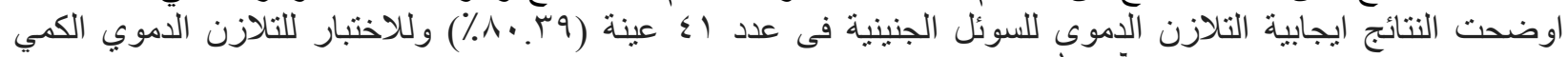

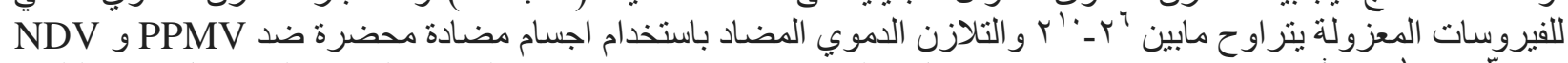

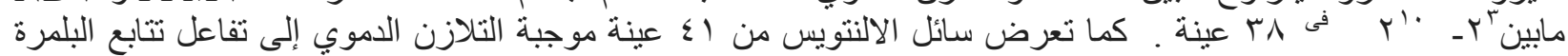

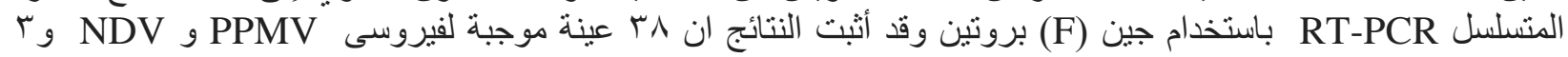

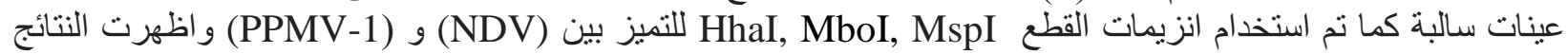

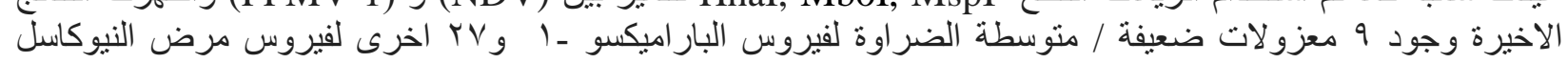

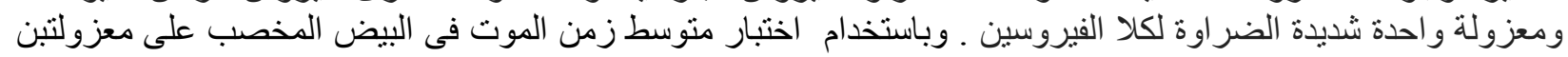

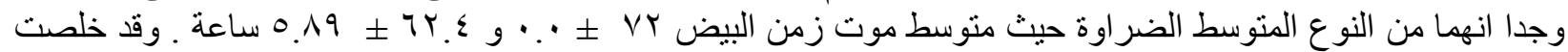

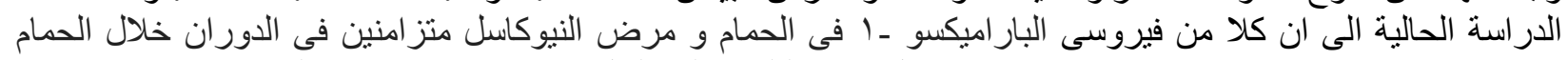

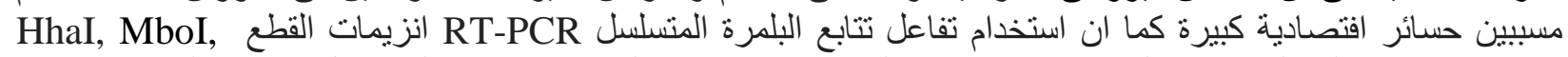

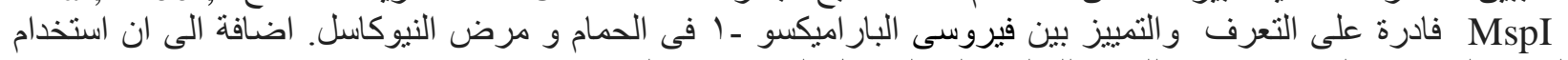

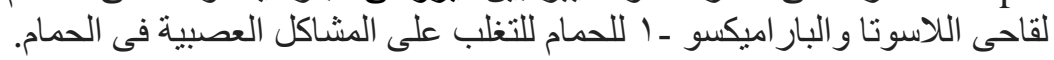

